\title{
Research on the choice of RMB exchange rate system Analysis based on the modified Mundell Fleming model
}

\author{
Qingqing YANG ${ }^{1}$, Jun $\mathrm{WU}^{2}$ \\ ${ }^{1}$ Department of Management, Hefei University of Technology Hefei, Anhui Province, China \\ ${ }^{2}$ Department of Management, Hefei University of Technology Hefei, Anhui Province, China \\ 115256086370@163.com
}

\begin{abstract}
First it analyses whether the Mundell- Fleming model is adapted to China and considers that the slope of balance line of international payment of China should be negative. Then it analyses and compares the advantage and disadvantage between the fixed exchange rate system and the floating one by using the modified Mundell-Fleming model when the economy of China is faced with the external impact, and it considers that floating exchange rate system is better than fixed exchange rate system in China.
\end{abstract}

Index Terms - Mundell-Fleming model the Balance Line of International Payment RMB Exchange Rate System

\section{Introduction}

Mundell Fleming model (M-F) is added the balance line of international payment (BP line) based on the IS-LM model, the model shows that:in the interest rate(r)and income(y)coordinate system, the slope of the balance line of international payments is positive, because the rise of interest rate can improve the balance-of-payments (by attracting capital inflows), while the increase of monetry income will deteriorate it (by deteriorating trade balance ) ${ }^{[1]}$, and in the exchange rate(S: This paper adopts direct quotation) and income (y) coordinate system, the slope of the balance line of international payments is also positive, because the rise of foreign exchange prices can improve the balance-of-payments and the increase of income will deteriorate it. In order to make the international balance of payments remain unchanged, therefore, the rise in the price of foreign exchange must be accompanied with higher output ${ }^{[1]}$, which means the improvement of the output must be accompanied with the devaluation of the national currency, then it can maintain their balance of payments. Chinese practical situation has witnessed that the import tariffs and interest rate constantly decline and the economy increases in high speed since China performed market economy in 1994. Meanwhile, the balance of international payments is in surplus constantly, and the surplus is widening year by year. The RMB exchange rate remains rising steadily, foreign exchange reserve is increasing greatly, which is contrary to the premise of the M-F model clearly.

\section{Literature review}

Scholars have modified M-F model and analyzed whether it is suitable for China. For example: Jiang Boke corrected the BP line of traditional M-F model. Modified M - F model assumed that the BP line was a broken line (its slope was still positive) ${ }^{[2]}$.Zhang Hejie, Chen Weili has changed the third condition in traditional M-F model from "there is no exchange rate changes expectations and investors are risk neutral," to "there is stable expectations that market will appreciate against the yuan ". But they thought that the slope of the BP curve was still positive in China and made a theoretical and positive analysis about effects of China's expansionary fiscal policy on national income in the frame of modified M-F mode ${ }^{[3]}$.Luo Yunfeng thought unlike the US economic growth pattern, China was export-oriented economy, whose slope of the BP line should be negative ${ }^{[4]}$.

Whether the slope of the BP line is positive or not in China? Namely, what's the functional mechanism of economic growth on exchange rate? There are two opposite viewpoints about the question in academic circles at home and abroad: one is that with the economic growth, the value of its monetary will be enhanced, so economic growth will lead to their monetary appreciation, such as the ppp, the monetary model of exchange rate and the Balassa-Samuelson effect; while the other is economic growth will increase imports, the devaluation of the current account will lead to their monetary deterioration, such as the Keynes trade multiplier theory and M-F model.

We assume that the BP line with positive slope is only likely to accord with Chinese reality in a very short time. At present, the scholars, however, don't put the model's application in a short time when using M-F model to analyze the Chinese realistic problems. What's worse, the effectiveness of macroeconomic policies are delayed. If it comforms to China's reality only in a very short period of time, the M-F model as a macroeconomic policy analysis tool has no meaning. So we need to modify the M-F model. In 2006, we had conducted a detailed study to China's BP line (see references [5], [6] and [8]), then concluded the slope of China's BP line should be negative and deduced China's BP line using geometry model. Next we will use the modified M-F model (in the M-F model, we call the BP line with negative slope is modified M-F model, the BP line with positive slope is traditional $\mathrm{M}-\mathrm{F}$ model) to research the choice of RMB exchange rate system.

\section{The choice of RMB exchange rate system under conditions of the open economy}

There are already some scholars using the traditional M-F model to analyze the issue of choice of RMB exchange-rate system, such as Sun Huayu. By analyzing M-F model and 
Dornbush exchange-rate Overshooting Model, he revealed that the choice of a nation's monetary and financial system was not the issue of " trilemma", which included the independence of currency policy, exchange-rate stability, and complete capital outflows. He holded that as long as facing the open economy, there would be an "dilemma" of the lacking independence of monetary policy. So the independence of monetary policy couldn't be the standard criterion of choosing the exchangerate system. What should be considered in the quite long historical period was that which of the two systems was more beneficial to sustained increase of economy ${ }^{[7]}$. Zhao Qingming, using the traditional M-F model, discussed the merits and demerits of the two models respectively when Chinese economy was confronted with practical shocks and financial shocks. He claimed that when restrictions on capital flows were comparatively rigid, the implement of fixed exchange rate system would exert positive effort on output stability; and when the capital accounts were convertible, the floating exchange rate system would work better. So there were emergency of two pairs of rational combinations: the fixed exchange rate system and capital and financial account, the floating exchange-rate system and capital account convertibility ${ }^{[8]}$.

Next we will use the modified M-F model to reexamine the choice of RMB exchange rate system.

On March 22, 2015, Zhou Xiaochuan, the governor of the people's Bank of China said in Beijing: China's "Twelfth FiveYear Plan" put forward to accelerate the realization of the RMB capital account convertibility, and 2015 is the last year of the "Twelfth Five-Year Plan", Therefore, we plan to achieve this goal through the efforts of all parties ${ }^{[9]}$.Actually, it has basically realized convertibility under current account and capital account.

As can be seen from Figure 1, we assume that the initial economic status is at the point of $\mathrm{A}$, where meanwhile keeps internal and external balance. If Chinese capital account is convertible, namely capital flows more flexible, BP curve should be relatively flat. So we can assume that Chinese economic level of balanced interest rate is the same as the international level of market interest rate, interest rate volatility will lead to rapidly change in capital flows. The following analysis is the impacts of the practial shocks and financial shocks on the Chinese output level under the different exchange rate system.

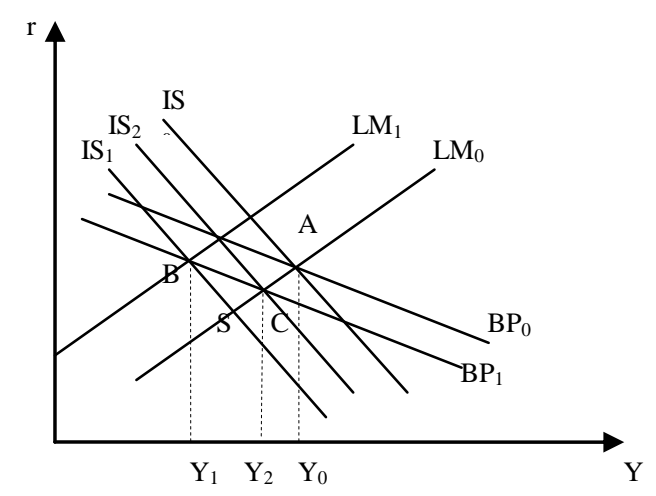

Figure 1 Effects of the practical shocks to China's economy under the condition of capital convertibility

\section{A. Effects of the practical shocks to China's economy}

Now supposed that China suddenly suffered from a certain practical shock, such as an abrupt descendant of net exports, it will make $\mathrm{IS}_{0}$ shift left to IS $\mathrm{S}_{1}$ by multiplier effect. At this time, the different exchange rate system will exert different effects on outputs.

\section{1) Adoption of fixed exchange rate system}

Practical shocks make the $\mathrm{IS}_{0}$ line shift left to $\mathrm{IS}_{1}$, which intersects curve $\mathrm{LM}_{0}$ to point $\mathrm{S}$. This joint point is under $\mathrm{BP}$ line so the balance of payments behaves as deficit. In order to maintain exchange rate stable, the central bank will buy domestic currency and throw foreign currency and then the domestic currency supply will decrease accordingly, $\mathrm{LM}_{0}$ line will shift left to $\mathrm{LM}_{1}$. The balance of Chinese economy will move to the point of B but not external balance. The internal and external equilibrium is irreconcilable under fixed exchange rate system. At this time, the level of domestic output is $Y_{1}$, which descended greatly compared with that before the practial shocks.

\section{2)Adoption of floating exchange rate system}

With the above analysis, practical shocks will make IS $_{0}$ curve shift left to IS $S_{1}$, which intersects the $\mathrm{LM}_{0}$ line to point of S. At this time, it just achieves internal balance, the international balance of payments is deficit. But due to adopting the floating exchange rate system, the central bank does not intervene in the monetary markets, the domestic monetary supply remains stable, so $\mathrm{LM}_{0}$ is invariable. Thus, the monetary will devalue automatically, which will cause $\mathrm{BP}_{0}$ line shift bottom left to $\mathrm{BP}_{1}$ (shown in Figure 1). At the same time, the devaluation of the monetary devaluation promotes exports and current account, so that the $\mathrm{IS}_{1}$ line shift right to $\mathrm{IS}_{2}$ gradually. Chinese economy realizes internal and external equilibrium at the point of $\mathrm{C}$. The equilibrium level of output is $\mathrm{Y}_{2}$ and its range of output reduction is smaller than the equilibrium output level $\left(\mathrm{Y}_{1}\right)$ with adopting fixed exchange rate system.

Through above contrast and analysis, we can draw the conclusion that under the circumstances of rigid capital account control, facing the practical stocks, floating exchange rate system is better than the fixed exchange rate system. 


\section{B. Effects of the financial shocks to Chinese economy}

It is assumed that open economy suffered from a sort of abrupt financial shocks (shown in Figure 2), such as an abrupt capital flight, which induces $\mathrm{BP}_{0}$ curve shift right to the position of $\mathrm{BP}_{1}$. The following analysis is the financial impacts on outputs caused by several different exchange-rate systems.

\section{1) Adoption of fixed exchange rate system}

Capital flight will lead to deficit in China's capital account in the international balance of payments under fixed exchange rate system. In order to make the exchange rate remain stable, the Central Bank must throw foreign currency and recycle its own currency, which will reduce native currency supply automatically. That is to say, $\mathbf{L M}_{0}$ line will shift left to $\mathrm{LM}_{1}$, which makes interest rates rise. Under the condition of capital account convertibility, the adjustment of interest rate and liquidity in the financial market is extremely fast. The rise in interest rate will make the capital return to China, which will improve chinese capital account quickly. The capital account from deficit to balance just in a short time, so the capital flight has little effect on the current account. We can assume that the $\mathrm{IS}_{0}$ line is unchanged, Chinese economy will achieve the internal and external equilibrium at the point of B. At this point, the equilibrium level of output falls to $Y_{1}$.

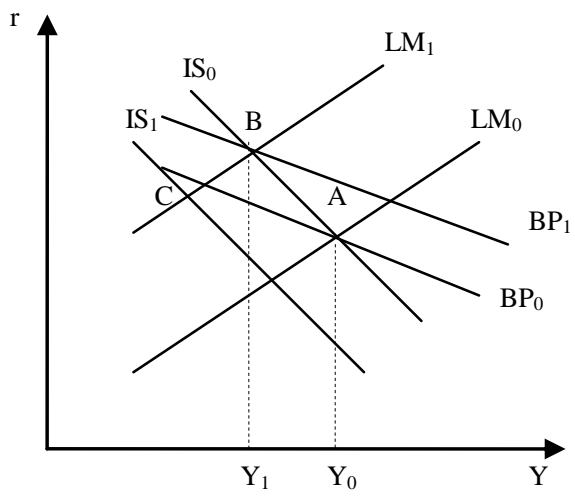

Figure 2 Effects of the financial shocks to china's economy under the condition of capital convertibility

\section{2) Adoption of floating exchange-rate system}

Capital flight leads to deficit in the international balance of payments. The reduction of investment makes $I_{0}$ shift left to IS ${ }_{1}$. However, because the Central Bank doesn't intervene in the foreign exchange market, so the currency supply will stay stable. $\mathrm{LM}_{0}$ line remains unchanged under floating exchange- rate system. In addition to the depreciation of native currency, $\mathrm{BP}_{1}$ line will go back to $\mathrm{BP}_{0}$. Devalued native currency is e beneficial for increasing the net export, which increases output by multiplier effect and improves current account. Namely, IS $_{1}$ shift right gradually to $\mathrm{IS}_{0}$. Finally, China reache to internal and external equilibrium again at point $\mathrm{A}$ and its balanced output level returns to $\mathrm{Y}_{0}$.

\section{Conclusion}

First it analyses whether the Mundell- Fleming model is adapted to China and considers that the slope of balance line of international payment of China should be negative. Then it analyses and compares the advantage and disadvantage between the fixed exchange rate system and the floating one by using the modified Mundell-Fleming model when the economy of China is faced with the external impact, and it considers that floating exchange rate system is better than fixed exchange rate system in China.

\section{Acknowledgment}

Compared with former analysis, whatever practical shocks or financial shocks, the adoption of floating exchange rate will be more beneficial to Chinese economic development than fixed exchange rate system in the condition of capital convertibility.

\section{References}

[1] Mundell. Mundell Economics (the third volume). Beijing: China Financial Publishing House, 2003: 41-111.

[2] Jiang Boke, Xu Hanjiang .The free convertibility of the RMB and capital controls. Shanghai: Fudan University press, 1999: 200 -238.

[3] Zhang Hejie, Chen Wei Li. Analysis on the impact of the expansionary fiscal policy on the internal and external balance. Statistic research, 2008 (10): 26-33.

[4] Luo Yunfeng. The effectiveness of Chinese fiscal policy: Adjustment and application of Mundell - Fleming model in the China. Shanghai economic research, 2010 (1): 3-11.

[5] Wu Jun, Zhou Yongwu, Wang Junfeng. The modification of Mundell Fleming model. The Journal of Quantitative \& Technical Economics, 2006 (6): $116-121$.

[6] Wu Jun, Yang Shanlin. Dynamic purchasing power parity theory and method. Hefei: He Fei University of Technology press, 2009.11.

[7] Sun Huayu. "Impossible Triangle" can not be basis for the choice of China's exchange rate system. International financial research, 2004 (8): 11-16.

[8] Zhao Qingming. Research on the RMB capital account convertibility and the internationalization Beijing: China Financial Publishing House, 2005.

[9] Central bank governor Zhou Xiaochuan: Convertibility of RMB capital account by 2015: http://business.sohu.com/20150322/n410136861.shtml. 